\title{
Emission of Carbon Dioxide of Selected Retailers
}

\author{
LUKIC Radojko ${ }^{23}$
}

\begin{abstract}
Increased attention has been paid recently to the analysis of the effects of applying the concept of sustainable development in retail. In that context we have particularly considered greenhouse gases emission in retail. This is achieved through the use of modern ecological technology in business - through the whole value chain. The ultimate goal is to achieve the planned reductions of carbon dioxide in retail, which positively reflects the overall performance of retailers, environmental in particular. The costs of carbon dioxide emission reduction affect the performance of retailers. Continuous empirical research shows that almost all global retailers achieve a significant reduction in carbon dioxide emissions from year to year.

Empirical research conducted in this paper on the example of global retailers in the United States, Europe and the European Union, the United Kingdom, Mexico, China, Croatia and Serbia shows significant and planned reduction of carbon dioxide emissions in retail, especially in countries with developed market economies. This empirical research is mainly based on the analysis of the original sustainable (environmental and ecological) reports officially disclosed by selected retailers, primarily from the countries of a developed market economies, which they started to publish with regular annual financial statements. They are now an integral part of the so-called integrated reporting on performance of global retailers. Due to the general importance, harmonized regulations on sustainable retail reporting are being increasingly applied as a data source for more efficient environmental management. In perspective, this will ease the comparative analysis of the carbon dioxide emission of global and other retailers.
\end{abstract}

Keywords: greenhouse gas emissions, carbon dioxide, $\mathrm{CO}_{2}$ emission sources, renewable energy sources, sustainable reporting

\section{JEL: I10, L81, M14, M41, Q42, Q56, Q57 \\ UDK: 005.346:504.5 \\ 658.26 \\ COBISS.SR-ID 253500684}

\section{Introduction}

Close attention has been recently devoted to the analysis of environmental performance in all sectors, including wholesale and retail trade. Within this, greenhouse gases emission (GHG) in retail is briefly considered. The overall goal of global retailers is to reduce carbon dioxide emissions through the entire value chain. The costs of carbon dioxide emission reduction are significant and affect the performance of retailers.

The subject of research in this paper is the significance and trend of carbon dioxide emissions in retail. Based on a comparative analysis of the original officially disclosed sustainable reports of global selective retailers, the aim of the research is to comprehensively examine the problem of carbon dioxide emissions in retail through an entire value chain and to

\footnotetext{
${ }^{23}$ Faculty of Economics, Belgrade, University of Belgrade, Serbia, rlukic@ekof.bg.ac.rs
} 
take appropriate measures to achieve the target reduction. The effects of this are the improvement of the overall, especially environmentally-friendly performances of retailers. In this we find the scientific and professional contribution of this work, due to the fact that there is scarce literature fully devoted to the issue of carbon dioxide emissions in retail.

Numerous factors undoubtedly influence carbon dioxide emissions in retail, and these are: type of store, product category, nature of the item itself, sales, location and distance (type of settlement: urban, suburban and rural), carbon policy (Wang et al., 2017), as well as energy sources, type of ventilation and heating of sales and other premises, cooling devices, mode of transport (logistics), waste treatment, and others. Taxation is also a factor in carbon dioxide emissions in all sectors, including retail (Qin, 2015). Regarding retail formats (types of stores, classical or modern - Internet shops) on-line sales have insignificant carbon dioxide emissions and, viewed through a value chain, it occurs only in warehousing, while in distribution and in the store, equals zero, contrary to the other types of stores (Seebauer et al., 2016). Carbon dioxide emissions vary by product category (food and non-food products) and within one product category, by individual articles, depending on their nature (Linda, 2014; Eriksson, 2017).

All in all, the main sources of carbon dioxide emissions in retail are: electricity, transport, ventilation and heating, refrigeration and waste. Effective control of the factors that influence the emission of carbon dioxide can significantly affect the improvement of economic, social and, in particular, environmental performance in retail. For these reasons, it is necessary to know the size and intensity of carbon dioxide emissions in modern retail, which is the focus of this work.

There is voluminous literature devoted to analyzing the way company's performance is affected by general problems and effects of carbon dioxide emission reduction through the whole chain (Jones, 2005; Martinuzzi, 2011; Kahn, 2014; Congcong, 2016; Li, 2016; Seebauer et al., 2016; Bazan, 2017, Clune, 2017), as well as consumer preferences (Ji, 2017). In other words, it is generally known that carbon dioxide reduction increases the economic performance of companies (Cusshiella, 2017), the profitability of producers and retailers, as well as consumer preferences (Eagle, 2017). In view of the significance of the problem of carbon dioxide emissions, generally speaking, as far as we know, the number of papers dedicated to the specificities and impacts of carbon dioxide emission reduction on the performance of retail companies is modest (Patten, 2014; Makarov, 2015; Riboldazzi, 2016; Sullian, 2016).

In Serbian literature this issue is only partially considered in some works (Lukic, 2011a, b, 2012, 2014, 2016a, b, c, 2017). For that reason, this paper attempts to make thorough analysis of specific issues of carbon dioxide emissions in the retail sector, firstly on the example of global retailers from different countries, primarily developed market economies, which, due to the general importance of the matter, publish reports on sustainable development with regular annual financial reports. This practice of global retailers provides them with more reliable information base for efficient management of carbon dioxide emissions through the whole value chain. This is particularly true for retailers in Serbia whose practice of making the reports on environment and sustainable development publicly available is at the very beginning.

The general research hypothesis in this paper is that the reduction of carbon dioxide emissions positively reflects on overall (integrated, especially environmental) performance of retailers. The methodology of the study of the given hypothesis is primarily based on the comparative analysis of the carbon dioxide emission of global selected retailers from various comparable countries of the developed market economy. The problem of comprehensiveness of the research on carbon dioxide emissions in retail is that, at the time being, there is no unified system of sustainable (environmental) reporting for all retailers. In addition, many retailers still do not publish this report, what as a consequence, has an incomplete "comparability" of data on carbon dioxide emissions by individual retailers. Nevertheless, knowledge of the importance and trend of carbon dioxide emissions from global retailers is very important in order to manage overall, integrated and, in particular, environmental performance in (concrete) retail. In view of 
the global, other retailers will increasingly publish reports on sustainable development (with data on carbon dioxide emissions). In this way, they will increase its information base for more efficient management of total business, including environmental protection. This will have a positive impact on the achievement of the target profit.

Main data sources for the research of the treated problem in this paper are literature, articles, publications, studies, OECD, Eurostat and, in particular, officially disclosed annual financial and sustainable reports of (global) retailers. They were processed in such a way that is easy to comprehend the significance and trend of carbon dioxide emission in retail.

\section{Carbon dioxide emissions in retail companies}

Different is the carbon dioxide emissions of individual retailers. This is shown by the results of the research in this paper.

At WalMart (United States of America, Dominant operational format: Hypermarket/Supercenter/Superstore), a great significance is given to reducing carbon dioxide emissions (Table 1). This is achieved by: investing in renewable energy sources, reducing energy demand, improving energy efficiency, improving refrigeration in stores and maximizing the efficiency of the vehicle fleet.

Table 1. Carbon dioxide emission (Scope 1 and 2) and retail area at WalMart, 2005-2014

\begin{tabular}{||l|l|l|l|l|l|l|l|l|l|l||}
\hline \hline & 2005 & 2006 & 2007 & 2008 & 2009 & 2010 & 2011 & 2012 & 2013 & 2014 \\
\hline $\begin{array}{l}\text { Carbon dioxide } \\
\text { emission (million- } \\
\text { ton } \mathrm{CO}_{2 \mathrm{e}} \text { ) }\end{array}$ & 18,9 & 19,3 & 20,1 & 20,8 & 20,3 & 20,6 & 20,8 & 21,2 & 21,0 & 21,9 \\
\hline $\begin{array}{l}\text { Retail area (million } \\
\text { square meters) }\end{array}$ & 740 & 805 & 867 & 921 & 952 & 985 & 1,037 & 1,072 & 1,102 & 1,134 \\
\hline $\begin{array}{l}\text { Carbon dioxide } \\
\text { intensity (million } \\
\text { tons CO} \mathrm{CO}_{2} / \text { million } \\
\mathrm{m}^{2}{ }^{*}\end{array}$ & 0,025 & 0,024 & 0,023 & 0,022 & 0,021 & 0,021 & 0,020 & 0,020 & 0,019 & 0,019 \\
\hline
\end{tabular}

Note: * Calculations performed by the author

Source: Wal-Mart Stores, Inc. 2016 Global Responsibility Report,

https://cdn.corporate.walmart.com/9c/73/3f9abcef444397f2c771e081e095/2016-global-responsibilityreport.pdf\#page $=58 \&$ zoom $=$ auto $,-130,628$

In generating greenhouse gas emissions, WalMart participates with: electricity supply $69 \%$, refrigeration $18 \%$, fuel transport $5.9 \%$, fuel on the site $7 \%$ and mobile refrigerators with $0.1 \%$ (Wal-Mart Stores, Inc. 2016 Global Responsibility Report, https://cdn.corporate.walmart.com/9c/73/3f9abcef444397f2c771e081e095/2016-global responsibility-report.pdf\#page=58\&zoom=auto, -130,628. Therefore, the main source of greenhouse gas emissions in WalMart is electricity supply. With the increased application of the ecological operation principles, WalMart reduced carbon dioxide emissions from year to year, which reflects favourably on its overall performance, especially environmental.
In
Kroger
(United
States,
Dominant
operational
format: Hypermarket/Supercenter/Superstore) carbon dioxide emissions amounted to 32.9 (tonnes of $\mathrm{CO}_{2} \mathrm{e} / 1,000 \mathrm{sq} \mathrm{ft}$ ) in 2015 , and 36.3 in 2006 . This means that there was a $9.3 \%$ reduction achieved (2016 Sustainability Report/Kroger, http://sustainability.kroger.com/environmentenergy-carbon.html. The effects of this decrease are the improvement of environmental and overall performance in the company Kroger.

In Best Buy (United States, Dominant operational format: Electronics Specialty), considerable attention is paid to the reduction of greenhouse gas emissions. This is shown in Table 2. 
Table 2. Energy and greenhouse gas emissions at Best Buy

\begin{tabular}{|c|c|}
\hline Key performance indicators & Data \\
\hline Energy consumption within organisation & $\begin{array}{l}\text { Fuel consumption: } 2,883,506,400,000,000 \text { joules } \\
\text { Electric energy consumption: } 1,074,586 \mathrm{MWh} \\
\text { Total Scope } 1 \& 2: 1,975,560 \mathrm{MWh}\end{array}$ \\
\hline Energy intensity & $0,0332275 \mathrm{MWh} / \mathrm{Sq} \mathrm{Ft}$ \\
\hline Energy consumption reduction & $34,415 \mathrm{MWh}$ or $1,8 \%$ reductions from year to year \\
\hline $\begin{array}{l}\text { Direct emission of greenhouse gasses (GHG) } \\
\text { (Scope 1) }\end{array}$ & $219,869 \mathrm{MT} \mathrm{CO}_{2 \mathrm{e}}$ \\
\hline $\begin{array}{l}\text { Indirect emission of greenhouse gasses (GHG) } \\
\text { (Scope 2) }\end{array}$ & $* 354,451 \mathrm{MTCO}_{2 \mathrm{e}}$ \\
\hline $\begin{array}{l}\text { Other indirect emission of greenhouse gasses } \\
\text { (GHG) (Scope 3) }\end{array}$ & $1,019,791 \mathrm{MT} \mathrm{CO}_{2 \mathrm{e}}$ \\
\hline Green House Gasses emission (GHG) intensity & $0.01017468 \mathrm{MTCO}_{2 \mathrm{e}} / \mathrm{Sq} \mathrm{Ft}$ \\
\hline Green House Gasses emission reduction (GHG) & $\begin{array}{l}{ }^{*} 120,444 \mathrm{MTCO}_{2 \mathrm{e}} \text {, or } 17,3 \% \text { reductions from year to } \\
\text { year }\end{array}$ \\
\hline
\end{tabular}

Note: *RECs (Renewable Energy Credits) not included

Source: Best Buy Fiscal Year 2016 Corporate Responsibility \& Sustainability Report, https://corporate.bestbuy.com/wp-content/uploads/2016/06/fy16-full-report-final.pdf

The data in the given table show that it is planned to achieve a significant reduction in emission of greenhouse gasses in Best Buy primarily by using renewable energy sources.
At
Tesco
(United
Kingdom,
Dominant
operational
format: Hypermarket/Supercenter/Superstore), as with WalMart, considerable attention is paid to the research and control of carbon dioxide emissions. This positively reflects on its overall performance, including the surrounding ones. In Figure 1, an illustration of the specificity of carbon dioxide emissions measurement at Tesco is shown.

Boundary for Direct Carbon Footprint

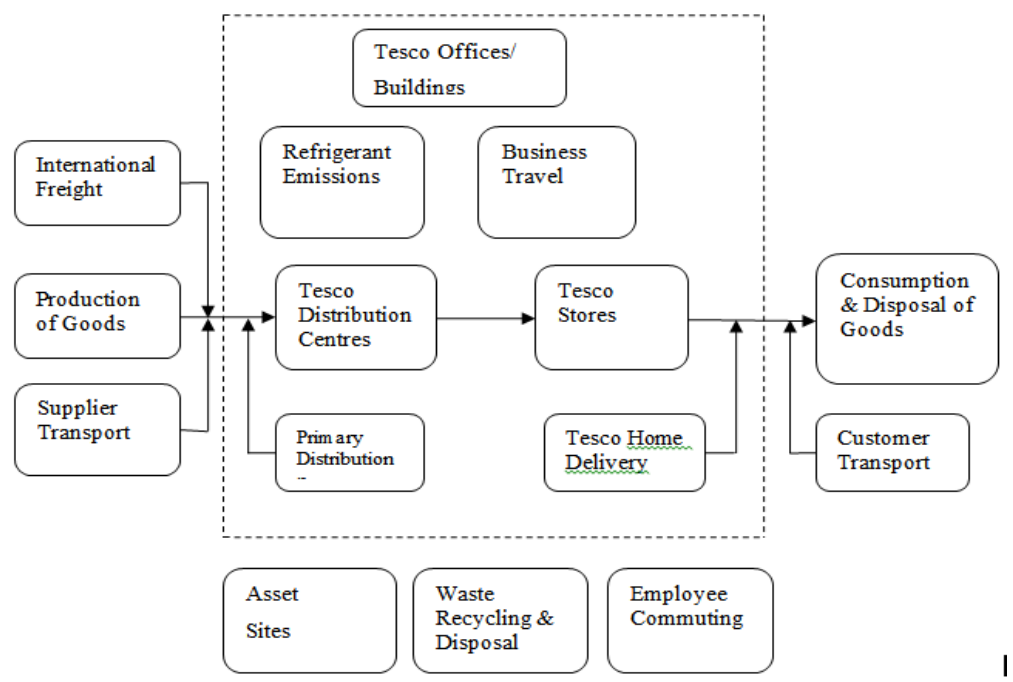

Fig. 1. Tesco's emission limit

Source: Carbon Footprint 101: A Guide for Food Retailers,

https://www.fmi.org/docs/sustainability/carbon-footprint-101-a-guide-for-foodretailers.pdf? sfvrsn $=4$ \#page $=11 \&$ zoom $=$ auto, -121.85

Table 3 and Figure 2 show the greenhouse gas emissions in Tesco.

Table 3. Emission of greenhouse gases in Tesco

\section{Total ton $\mathrm{CO}_{2 \mathrm{e}}$}

$2016 / 17$

$2015 / 16$

Base year 


\begin{tabular}{|l|l|l|l|}
\hline & & & $2006 / 07$ \\
\hline Scope 1 & $1,236,980$ & $1,301,746$ & $1,345,507$ \\
\hline Scope 2 & & & \\
\hline Market-based method & $1,582,275$ & $2,004,992$ & Not available \\
\hline Location-based method & $2,357,245$ & $2,528,323$ & $2,259,984$ \\
\hline $\begin{array}{l}\text { Scope 1 and 2 carbon } \\
\text { dioxide intensity (kgCO } 2 \mathrm{e} / \mathrm{sq} \\
\text { ft of stores and distributive } \\
\text { centres) }\end{array}$ & 22,95 & 26,33 & 51,14 \\
\hline Scope 3 & $1,073,721$ & $1,097,491$ & $1,064,460$ \\
\hline Total gross emission & $3,892,977$ & $4,404,230$ & $4,669,951$ \\
\hline $\begin{array}{l}\text { CO } 2 \mathrm{e} \text { from renewable energy } \\
\text { exported to the grid }\end{array}$ & 1,154 & 1,513 & - \\
\hline Total net emissions & $3,891,822$ & $4,402,717$ & $4,669,951$ \\
\hline $\begin{array}{l}\text { Overall net carbon intensity } \\
\text { total net emissions } \\
\text { kgCO } 2 \mathrm{e} / \text { sq ft of stores and } \\
\text { distributive centres) }\end{array}$ & 31,69 & 35,06 & 66,23 \\
\hline
\end{tabular}

Source: Tesco PLC Annual Report and Financial Statements 2017,

https://www.tescoplc.com/media/392373/68336_tesco_ar_digital_interactive_250417.pdf

The data in the given table show that the intensity of carbon dioxide emissions in Tesco is decreasing from year to year.

\section{6/17 total carbon footprint (million tonnes CO2e)}

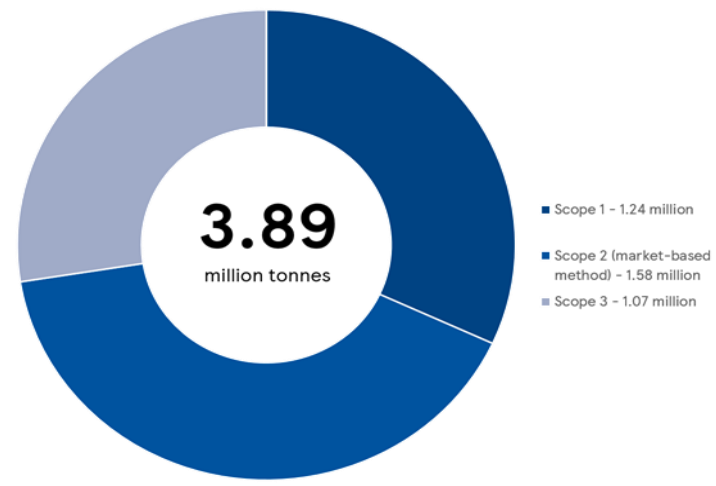

Fig. 2. Total carbon dioxide (million tonnes of $\mathrm{CO}_{2} \mathrm{e}$ ) in Tesco 2016/2017

Source: Tesco - Our carbon footprint, https://www.tescoplc.com/tesco-and-society/sourcing-greatproducts/reducing-our-impact-on-the-environment/our-carbon-footprint/

Figure 3 shows sources of carbon dioxide emission throughout the value chain, with an emphasis on Tesco's participation in carbon footprint. 


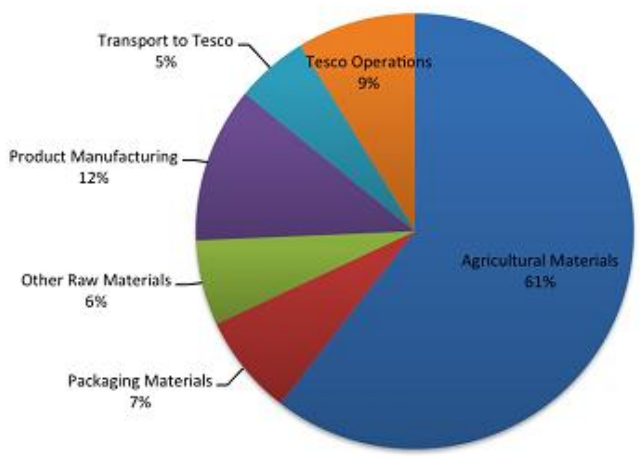

Fig. 3. Emissions of carbon dioxide by source in Tesco

Source: Tesco - Our Carbon Footprint, https://www.tescoplc.com/tesco-and-society/sourcing-greatproducts/reducing-our-impact-on-the-environment/our-carbon-footprint/

Therefore, Tesco participated in total emission of carbon dioxide through entire value chain with $9 \%$. Table 4 shows ecological performances at Tesco.

Table 4. Global ecological performances at Tesco

\begin{tabular}{||l|l|l|l|l|}
\hline & $2016 / 17$ & $2015 / 16$ & $2014 / 15$ & $2013 / 14$ \\
\hline Carbon dioxide (million-ton $\mathrm{CO}_{2 \mathrm{e}}$ ) & 3,9 & 5,1 & 5,26 & - \\
\hline $\begin{array}{l}\text { Emission of } \mathrm{CO}_{2} \text { reduction (stores and distributional centres) } \\
\text { compared to } 2006 / 07\end{array}$ & $40,5 \%$ & $39,5 \%$ & $38,3 \%$ & - \\
\hline $\begin{array}{l}\text { Emission of } \mathrm{CO}_{2} \text { reduction (distribution) compared to } \\
2011 / 12\end{array}$ & $19,7 \%$ & $17.4 \%$ & $14,47 \%$ & $7,8 \%$ \\
\hline Direct water consumption (million m ${ }^{3}$ ) & 23,5 & 25,5 & 32,6 & 32,9 \\
\hline $\begin{array}{l}\text { Waste percentage (food and non-food) which is recycled, } \\
\text { used again or turn into energy }\end{array}$ & $93 \%$ & $88 \%$ & $84 \%$ & $86 \%$ \\
\hline
\end{tabular}

Source: Reducing our impact on the environment,

https://www.tescoplc.com/tesco-and-society/sourcing-great-products/reducing-our-impact-on-theenvironment/

Tesco has tendency to improve ecological performances (carbon dioxide emission reduction, direct water consumption reduction and waste treatment improvement). This reflects favourably on its market, economic and financial performances.

Due to the increasing importance, special attention is paid to carbon dioxide emissions in Marks \& Spencer (M \& S) (United Kingdom, Dominant Operating Format: Department Store), as shown in Table 5.

Table 5. Emission of carbon dioxide in Marks \& Spencer

\begin{tabular}{|c|c|c|c|c|c|}
\hline & $\begin{array}{l}\text { Plan A } \\
\text { baseline } \\
2006 / 7 \\
(000 \\
\left.\mathrm{tCO}_{2 \mathrm{e}}\right)\end{array}$ & $\begin{array}{l}\text { Legal } \\
\text { baseline } \\
2013 / 14 \\
(000 \\
\left.\mathrm{tCO}_{2 \mathrm{e}}\right)\end{array}$ & $\begin{array}{l}\text { Last year } \\
2014 / 15 \\
(000 \\
\left.\mathrm{tCO}_{2 \mathrm{e}}\right)\end{array}$ & $\begin{array}{l}2015 / 16 \\
000 \\
\mathrm{tCO}_{2 \mathrm{e}}\end{array}$ & $\begin{array}{l}\text { Achievement in } \\
\text { relation to } 2006 / 7\end{array}$ \\
\hline $\begin{array}{l}\text { Total gross/location-based } \\
\text { emission } \mathrm{CO}_{2 \mathrm{e}}\end{array}$ & 732 & 567 & 592 & 566 & $-23 \%$ \\
\hline $\begin{array}{l}\text { Total carbon intensity measure } \\
\text { (per } 1000 \mathrm{sq} \mathrm{ft} \text { of sales floor (ton } \\
\mathrm{CO}_{2 \mathrm{e}} / 1,000 \mathrm{sq} \mathrm{ft} \text { ) }\end{array}$ & 46 & 30 & 30 & 29 & $-47 \%$ \\
\hline
\end{tabular}

Source: $M$ \& S Plan Report 2016,

http://annualreport.marksandspencer.com/M\&S_PlanA_Report_2016.pdf 
At Marks \& Spencer, a decrease in carbon dioxide emissions was recorded in 2014/15 in relation to 2006/7. Reduction was achieved by improving energy efficiency using the so-called "green energy" through the whole value chain. In Kingfisher (United Kingdom, Dominant operational format: Home improvement), significant attention is paid to carbon dioxide emissions. Table 6 shows the dynamics of greenhouse gas emissions at Kingfisher.

Table 6. Emission of greenhouse gases in Kingfisher (tons of $\mathrm{CO}_{2}$ e)

\begin{tabular}{||l|l|l|l|c||}
\hline \multicolumn{1}{|l|}{$\begin{array}{l}\text { Carbon footprint from fuel combustion and factories } \\
\text { (scope 1) }\end{array}$} & $2010 / 1$ & $2013 / 14$ & $2014 / 15$ & $2015 / 16$ \\
\hline $\begin{array}{l}\text { Carbon footprint from electricity, heating and steam } \\
\text { (scope 2) }\end{array}$ & $247,774,97$ & $230,759,93$ & $258,392,29$ & 246,775 \\
\hline $\begin{array}{l}\text { Absolute carbon footprint (scope 1 and 2) (aimed at } \\
25 \% \text { reduction until 2020) }\end{array}$ & $405,365,07$ & $394,932,89$ & $405,198,94$ & 402,837 \\
\hline Carbon footprint per $m^{2}$ of sales area & 61,00 & 56,27 & 53,26 & 51,9 \\
\hline
\end{tabular}

Company Kingfisher achieved a reduction of greenhouse gas emissions by 5\% 2015/16 compared to $2010 / 11$. Their goal is to achieve a reduction of up to $25 \%$ by 2020 . Kingfisher has been decreasing greenhouse gas emissions from year to year. In IKEA company (Sweden, Dominant operational format: Other Specialty) that operates with furniture, considerable attention is paid to improving the research methodology and the greenhouse gas emission control system. This is shown in Table 7.

Table 7. Emissions of carbon dioxide in IKEA, 2016

\begin{tabular}{|l|l||}
\hline & $\mathrm{FY} 2016$ \\
\hline Carbon footprint (tonnes $\mathrm{CO}_{2}$ ) & \\
\hline Scope 1 & 209,484 \\
\hline Scope 2 & 621,932 \\
\hline Scope 3 & $39,161,131$ \\
\hline Total & $39,992,548$ \\
\hline Carbon footprint at each stage of value chain (tonnes $\mathrm{CO}_{2}$ ) & \\
\hline Raw material & $16,562,759$ \\
\hline Production and distribution & $3,142,796$ \\
\hline Suppliers (home furnishing and catalogue) & $2,199,035$ \\
\hline Goods transport & 943,761 \\
\hline IKEA Group operations & $1,020,366$ \\
\hline Scope I and 2 from IKEA operations & 831,416 \\
\hline Business travel & 52,368 \\
\hline Co-worker commuting & 136,582 \\
\hline Shopping centre tenants & 172,373 \\
\hline Customers & $18,162,615$ \\
\hline Transportation to stores & $3,480,107$ \\
\hline Product use (light sources and appliances) & $14,682,507$ \\
\hline Products' “end of life" & 931,639 \\
\hline Total & $39,992,548$ \\
\hline
\end{tabular}

Source: IKEA Group - Sustainability Report FY16,

http://www.ikea.com/ms/en_US/img/ad_content/IKEA_Group_Sustainability_Report_FY16.pdf

Table 8 shows the efficiency of carbon footprint in IKEA. 
Table 8. Carbon efficiency in the company IKEA

\begin{tabular}{|c|c|c|c|c|c|}
\hline & FY10 & FY14 & FY15 & $\begin{array}{l}\text { FY16 (excluding } \\
\text { IKEA centres) }\end{array}$ & $\begin{array}{l}\text { FY16 (including } \\
\text { IKEA centres) }\end{array}$ \\
\hline $\mathrm{Kg} \mathrm{CO}_{2}$ per $\mathrm{m}^{3}$ product sold & 34,3 & 27,5 & 24,4 & 17,5 & 32,8 \\
\hline \multicolumn{6}{|c|}{ Carbon efficiency (\% improvement against FY10 baselines) } \\
\hline & FY10 & FY14 & FY15 & FY16 & FY20 goal \\
\hline Retail & & 37,8 & 39,6 & 48,0 & 50 \\
\hline Distribution centres & & 51,2 & 54,1 & 58,2 & 50 \\
\hline $\begin{array}{l}\text { IKEA Industry Group Divisions } \\
\text { flat line and Solid Wood }\end{array}$ & & 18,3 & 30,9 & 71,0 & 50 \\
\hline $\begin{array}{l}\text { IKEA Industry Group Division } \\
\text { Board }\end{array}$ & & 3,0 & 18,7 & 36,4 & 50 \\
\hline $\begin{array}{l}\text { IKEA components (base year } \\
\text { FY13) }\end{array}$ & & 7,8 & 33,8 & 35,8 & 50 \\
\hline Total & & 19,8 & 28,9 & 49,0 & 50 \\
\hline \multicolumn{5}{|c|}{ IKEA Carbon footprint from consumed electricity in FY16 } & FY16 \\
\hline \multicolumn{5}{|c|}{ Consumed electricity (MWh) } & $3,008,893$ \\
\hline \multicolumn{5}{|c|}{ Location based emissions (tonnes $\mathrm{CO}_{2}$ ) } & $1,266,578$ \\
\hline \multicolumn{5}{|c|}{ Market based emissions (tonnes $\mathrm{CO}_{2}$ ) } & 578,551 \\
\hline \multicolumn{5}{|c|}{ Footprint reduction from using electricity from renewable sources (\%) } & 54,3 \\
\hline
\end{tabular}

Source: IKEA Group - Sustainability Report FY16,

http://www.ikea.com/ms/en_US/img/ad_content/IKEA_Group_Sustainability_Report_FY16.pdf

In IKEA, significant reduction in carbon footprint is achieved through the growing use of renewable energy. The share of renewable resources in the total consumption of electricity in IKEA year after year was as follows: FY14 - 40\%, FY15 - 53.4\% and FY16 - 71.0\% (IKEA Group - Sustainability Report FY16, http://www.ikea.com/ms/en_US/img/ad_ content/IKEA_Group_Sustainability_Report_FY16.pdf. Increased consumption of the so-called "green energy" has had a positive impact on the IKEA's environmental and overall performance. Also, company IKEA pays significant attention to improving the transport system (logistics) in order to reduce carbon dioxide emissions. This is shown in Table 9.

Table 9. Product transport efficiency (impact on carbon dioxide emissions) in IKEA

\begin{tabular}{||l|l|l|l|l||}
\hline \hline & FY14 & FY15 & FY16 & $\begin{array}{l}\text { FY20 } \\
\text { goal }\end{array}$ \\
\hline $\mathrm{CO}_{2}$ per cubic meter of products transported & 32,7 & 28,2 & 26,6 & - \\
\hline $\begin{array}{l}\text { Reduction in } \mathrm{CO}_{2} \text { per cubic meter of products transported compared } \\
\text { with FY11 }(\%)\end{array}$ & 12,3 & 24,4 & 26,7 & 30 \\
\hline
\end{tabular}

Source: IKEA Group - Sustainability Report FY16,

http://www.ikea.com/ms/en_US/img/ad_content/IKEA_Group_Sustainability_Report_FY16.pdf

It is a general conclusion that IKEA has increased reduction of carbon dioxide emissions, which reflects favourably on its overall performance, in particular its environment.

At H \& M Group (Sweden, Dominant operational format: Apparel/Footwear Specialty), considerable attention is paid to the reduction of carbon dioxide emissions. This is shown in Table 10. 
Table 10. Carbon dioxide emission at H \& M Group

\begin{tabular}{||l|l|l|l|l|l||}
\hline \hline & 2012 & 2013 & 2014 & 2015 & 2016 \\
\hline $\begin{array}{l}\text { Carbon emissions per million SEK sales turnover } \\
\text { including VAT (constant exchange rate) }\end{array}$ & $2,04 \mathrm{t}$ & $2,05 \mathrm{t}$ & $1,72 \mathrm{t}$ & $0,69 \mathrm{t}$ & $0,36 \mathrm{t}$ \\
\hline $\begin{array}{l}\text { Total } \mathrm{CO}_{2 \mathrm{e}} \text { emissions to previous year in \% (Scope 1 } \\
\text { and 2) versus growth in sales (in local currencies) }\end{array}$ & & & & & \\
\hline Net sales & & $9 \%$ & $14 \%$ & $11 \%$ & $7 \%$ \\
\hline Emissions & & $356,373 \mathrm{t}$ & $341,675 \mathrm{t}$ & $151,753 \mathrm{t}$ & $80,54 \mathrm{t}$ \\
\hline
\end{tabular}

\section{Note: $S E C$ - Swedish crown}

Source: The H \& M Group sustainability report 2016 ,

http://sustainability.hm.com/content/dam/hm/about/documents/en/CSR/Report\%202016/HM_group_Sustai nabilityReport_2016_FullReport_en.pdf

In 2016, H \& M made a reduction of carbon dioxide emissions by $47 \%$ compared to 2015.

In Inditex Group (Spain, Dominant Operating Format: Apparel/Footwear Specialty), to which Zara also belongs, considerable attention is paid to research on carbon dioxide emissions and its reduction. This is shown in Table 11.

Table 11. Emission of greenhouse gases in Inditex

\begin{tabular}{||l|l|l|l|l||}
\hline & 2012 & 2013 & 2014 & 2015 \\
\hline Scope 1 $\left(\mathrm{tCO}_{2 \mathrm{eq}}\right)$ & 24,479 & 22,528 & 21,347 & 22,996 \\
\hline Scope 2 $\left(\mathrm{t} \mathrm{CO}_{2 \mathrm{eq}}\right)$ & 589,758 & 627,982 & 666,188 & 622,879 \\
\hline Number of clothes sold on the market & $869,167,058$ & $948,745,988$ & $1,018,995,911$ & $1,177,784,343$ \\
\hline $\mathrm{CO}_{2}$ per item sold on market & 706,70 & 685,65 & 674,72 & 548,38 \\
\hline $\begin{array}{l}\text { Avoided emissions by using generators } \\
\left.\text { of thermal energy ( } \mathrm{tCO}_{2 \mathrm{qq}}\right)\end{array}$ & $\mathrm{NA}$ & $\mathrm{NA}$ & $\mathrm{NA}$ & $5,339,59$ \\
\hline $\begin{array}{l}\text { Scope 3 Downstream transportation } \\
\left(\mathrm{tCO}_{2 \mathrm{eq}}\right)\end{array}$ & 398,168 & 462,120 & 596,316 & 672,307 \\
\hline $\begin{array}{l}\mathrm{Scope} 3 \text { Upstream transportation } \\
\left(\mathrm{tCO}_{2 \mathrm{eq}}\right)\end{array}$ & $\mathrm{NA}$ & $\mathrm{NA}$ & $\mathrm{NA}$ & 42,258 \\
\hline Scope 3 Franchise stores $\left(\mathrm{tCO}_{2 \mathrm{eq}}\right)$ & 100,143 & 108,035 & 113,094 & 94,262 \\
\hline
\end{tabular}

Note. NA - not available

Source: Inditex - Annual Report 2015

https://www.inditex.com/documents/10279/205236/Inditex + Annual+Report $+2015+$ web.pdf/9979097b9e63-489a-ad16-a141b6b665b4

Therefore, the result of efficient management is the reduction of carbon dioxide emissions in Inditex.

In 2015, Carefour (France, Dominant operational format: Hypermarket/Supercenter/Superstore) emitted 3.61 million tonnes of $\mathrm{CO}_{2} \mathrm{e}$. In 2015, carbon dioxide emissions were reduced by $29.7 \%$ compared to 2010 . The aim is to achieve a reduction in carbon dioxide emissions by $40 \%$ until 2025 and $70 \%$ until 2050 (Unique and Multiple/2015 Annual Activity and Responsible Commitment Report, http://www.carrefour.com/sites/default/files/carrefour_2015_annual_activity_and_responsible_ commitment_report.pdf. This will have a positive impact on Careffour's environmental and overall performance).

Metro Group (Germany, Dominant operational format: Cash \& Carry/Warehouse Club) regularly discloses reports on corporate responsibility, in which carbon dioxide emissions are represented in particular, as shown in the Table 12. 
Table 12. Greenhouse gas emissions in Metro Group (tonnes of CO2e)

\begin{tabular}{||l|l|l|l|l|}
\hline \hline & $\begin{array}{l}\text { Year of } \\
\text { reference } \\
2011\end{array}$ & $2013 / 14$ & $2014 / 15$ & $2015 / 16$ \\
\hline Scope 1- direct emission of greenhouse gasses & $1,084,509$ & $1,015,598$ & 871,837 & 760,186 \\
\hline $\begin{array}{l}\text { Scope 2 - indirect emission of greenhouse } \\
\text { gasses }\end{array}$ & $2,432,102$ & $1,786,594$ & $1,495,710$ & $1,416,418$ \\
\hline $\begin{array}{l}\text { Scope 3- other indirect emission of greenhouse } \\
\text { gasses }\end{array}$ & $6,113,122$ & $5,562,362$ & $5,151,775$ & $4,589,161$ \\
\hline Total emission of greenhouse gasses & $9,629,733$ & $8,364,553$ & $7,519,322$ & $6,765,764$ \\
\hline
\end{tabular}

Source: Metro Group - Corporate Responsibility Report 2015/16 - Key Performance

Indicators and Goals, https://www.metrogroup.de/.../reports/metro-group-corporate-responsibility-report2015

Data in this table show that Metro Group reduces emissions of greenhouse gases from year to year. The intensity of carbon dioxide emissions is reduced from year after year (Fig. 4).

This reflects favourably on its overall performance, including environmental.

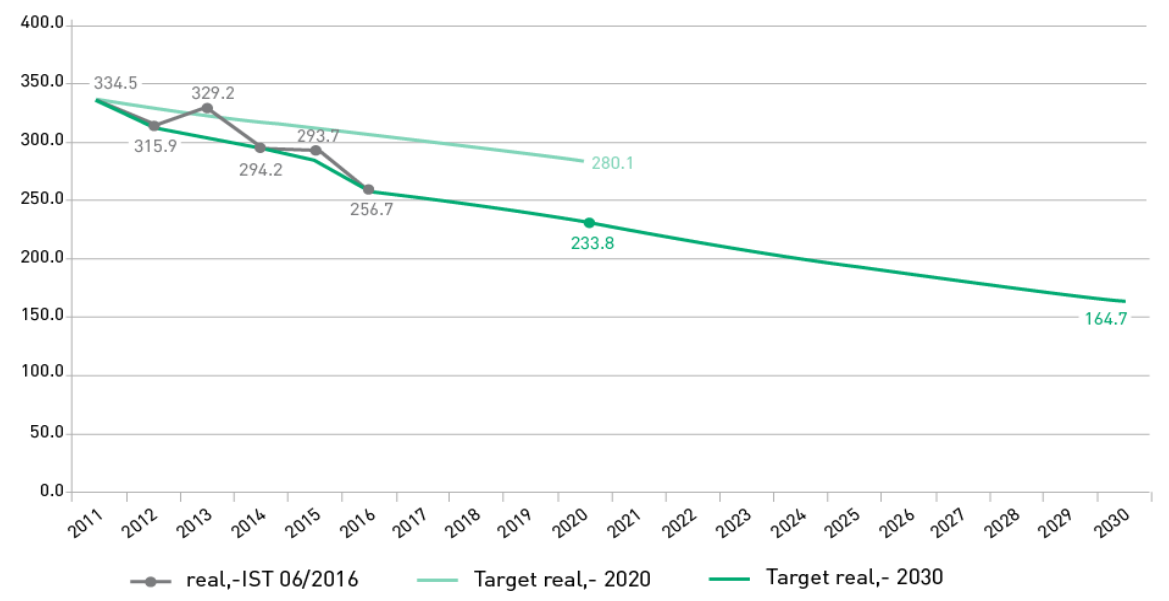

Fig. 4. Emission of carbon dioxide in Metro Group

$\left(\mathrm{kgCO}_{2} / \mathrm{m}^{2}\right.$ of sales area (referring to total sales space 2,003,960 $\left.\mathrm{m}^{2}\right)$

Source: Metro Group - Corporate Responsibility Report 2015/16 - Key Performance Indicators and

Goals, https://www.metrogroup.de/.../reports/metro-group-corporate-responsibility-report-2015

Aldi (Germany, Dominant operational format: Discount Store) also publishes reports on sustainable development, in which special attention is paid to the emission of carbon dioxide.

Table 12 shows the greenhouse gas emissions at Aldi.

Table 12. Greenhouse gases emission in Aldi (tons $\mathrm{CO}_{2} \mathrm{e}$ )

\begin{tabular}{||l|l|l||}
\hline \hline & 2014 & 2015 \\
\hline Scope 1 & 284,831 & 312,940 \\
\hline Scope 2 & 369,961 & 567,424 \\
\hline Total & 654,792 & 680,364 \\
\hline
\end{tabular}

Source: Aldi - Sustainability Report 2015, https://www.cr-aldinord.com/2015/wpcontent/uploads/sites/2/2016/04/ALDI_North_Group_NHB_Sustainability_Report_2015.pdf

At Aldi, greenhouse gases emissions by sectors (in percent) in 2015 were as follows: electricity $53.1 \%$, cooling equipment $20.0 \%$, heating energy $14.3 \%$ and logistics $12.6 \%$ (Aldi Sustainability Report 2015, https://www.cr-aldinord.com/2015/wpcontent/uploads/sites/2/2016/04/ALDI_North_Group_NHB_Sustainability_Report_2015.pdf. 
In order to reduce greenhouse gas emissions, special attention is paid to the use of energy from renewable sources (LED lamps).

At Ahold (Germany, Dominant operational format: Supermarket), considerable attention is paid to the reduction of carbon dioxide emissions. This is shown in Table 13.

Table 13. Carbon dioxide emission at Ahold

\begin{tabular}{||l|l|l|l|l|l|l|l|l|}
\hline & 2008 & 2009 & 2010 & 2011 & 2012 & 2013 & 2014 & 2015 \\
\hline $\begin{array}{l}\text { Carbon dioxide emissions (thousand } \\
\text { tons) }\end{array}$ & & & & 2,176 & 2,106 & 2,107 & 2,090 & 2,019 \\
$\begin{array}{l}\text { Carbon dioxide emissions }\left(\mathrm{kg} \mathrm{CO}_{2} / \mathrm{m}^{2}\right. \\
\text { sales area) }\end{array}$ & 567 & 574 & 543 & 507 & 480 & 473 & 465 & 420 \\
\hline Sources (\%) & & & & & & & & $49 \%$ \\
\hline Electricity & & & & & & & & $29 \%$ \\
\hline Refrigerant appliances & & & & & & & & $12 \%$ \\
\hline Fuel & & & & & & & & $10 \%$ \\
\hline Gas
\end{tabular}

Source: Ahold - Responsible Retailing Report 2015,

https://www.aholddelhaize.com/media/1934/ahold-responsible-retailing-report-2015.pdf

Carbon dioxide emissions at Ahold has been decreasing year after year. Since 2016, Ahold has been operating under the name of Ahold Delhaize. In view of this, Table 14 shows data on carbon dioxide emissions for Ahold Delhaize (Belgium, Dominant operational format: Supermarket) in 2016.

Table 14. Carbon dioxide emission at Ahold Delhaize

\begin{tabular}{||l|l|l||}
\hline & $\begin{array}{l}2016 \\
\text { Actuals }\end{array}$ & $\begin{array}{l}2020 \\
\text { Target }\end{array}$ \\
\hline $\begin{array}{l}\text { \% reduction in } \mathrm{CO}_{2} \text { equivalent emissions per } \mathrm{m}^{2} \text { of sales area (from } 2008 \\
\text { baseline) }\end{array}$ & $-22 \%$ & $-30 \%$ \\
\hline $\begin{array}{l}\text { Total } \mathrm{CO}_{2} \text { equivalent emissions per } \mathrm{m}^{2} \text { of sales area - location-based } \\
\text { approach }\end{array}$ & 496 & $\mathrm{n} / \mathrm{a}$ \\
\hline Total $\mathrm{CO}_{2}$ equivalent emissions (thousand tonnes) - location-based approach & 4,505 & $\mathrm{n} / \mathrm{a}$ \\
\hline $\begin{array}{l}\text { Total } \mathrm{Scope} 1 \mathrm{CO}_{2} \text { equivalent emissions (thousand tonnes) - location-based } \\
\text { approach }\end{array}$ & 1,940 & $\mathrm{n} / \mathrm{a}$ \\
\hline $\begin{array}{l}\text { Total Scope } 2 \mathrm{CO}_{2} \text { equivalent emissions (thousand tonnes) - location-based } \\
\text { approach }\end{array}$ & 2,420 & $\mathrm{n} / \mathrm{a}$ \\
\hline $\begin{array}{l}\text { Total } \mathrm{Scope} 3 \mathrm{CO}_{2} \text { equivalent emissions (thousand tonnes) - location-based } \\
\text { approach }\end{array}$ & 144 & $\mathrm{n} / \mathrm{a}$ \\
\hline Offset $\mathrm{CO}_{2}$ equivalent emissions (thousand tonnes) & 241 & $\mathrm{n} / \mathrm{a}$ \\
\hline Avoided grid electricity $\mathrm{CO}_{2}$ emissions (thousand tonnes) & 31 & $\mathrm{n} / \mathrm{a}$ \\
\hline
\end{tabular}

Source: Ahold Delhaize Supplementary report on Sustainable Retailing performance 2016, https://www.aholddelhaize.com/media/3984/supplementary-report-on-sustainable-retailing-performance2016.pdf

Significant reduction in carbon dioxide emissions by 2020 (30\%) is expected at Ahold Delhaize. This will be achieved by using so-called "green energy" in business operations.

Sources of carbon dioxide emissions were: electricity $60 \%$, cooling devices $31 \%$ and transport 9\% (Ahold Delhaize Supplementary Report on Sustainable Retailing performance 2016, https://www.aholddelhaize.com/media/3984/supplementary-report-on-sustainableretailing-performance-2016.pdf. Delhaize Serbia is also part of Ahold Delhaize which employs the same sustainable development strategy and environment reporting as well as company at its higher organizational level. 
In the Fast Retailing (Japan, Dominant Operating Format: Apparel/Footwear Specialty), exceptional attention is devoted to the issue of carbon dioxide emission reduction. Figure 5 shows carbon dioxide emissions through the entire value chain in Fast Retailing.

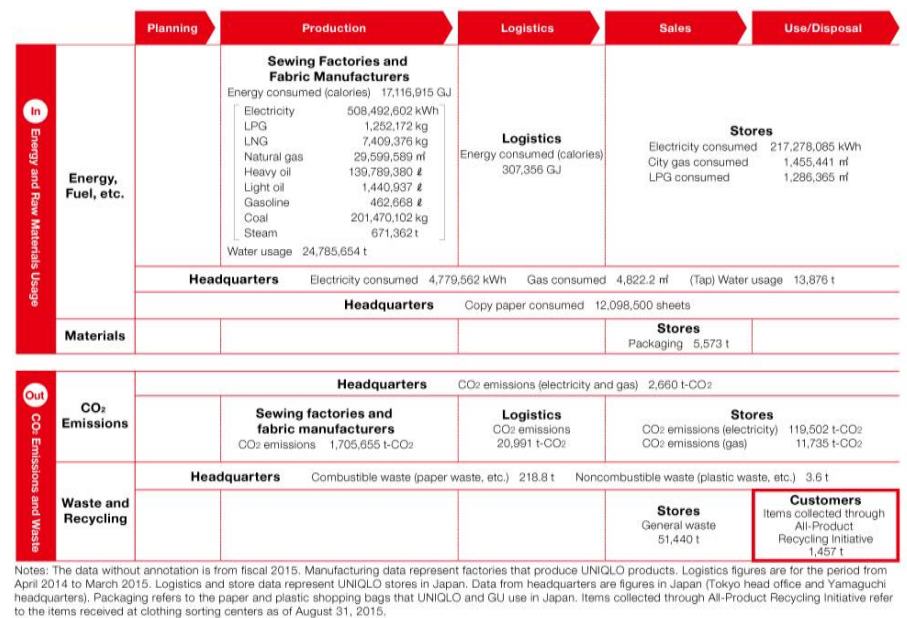

Fig. 5. Sustainable reporting - Carbon dioxide emission through value chain in Fast Retailing Source. Fast Retailing - Sustainability Report,

http://www.fastretailing.com/eng/sustainability/environment/co2_popup.html

In 2016, at Fast Retailing, carbon dioxide emissions amounted to 2,917,069 ( $\left.\mathrm{tCO}_{2 \mathrm{e}}\right)$. In logistics it was $17,707\left(\mathrm{tCO}_{2 \mathrm{e}}\right)$. Table 15 presents carbon dioxide emission $\left(\mathrm{tCO}_{2 \mathrm{e}}\right)$ in stores and management offices by sources (generators) at Fast Retailing for 2016.

Table 15. Carbon dioxide emission in stores and management according to sources (generators) at Fast Retailing for $2016(\mathrm{tCO} 2 \mathrm{e})$

\begin{tabular}{||l|l|}
\hline Store gas & 11,436 \\
\hline HQ gas & 38 \\
\hline $\begin{array}{l}\text { Total } \\
\text { Scope } 1\end{array}$ & 11,474 \\
\hline Store electricity & 123,932 \\
\hline HQ electricity & 2,466 \\
\hline $\begin{array}{l}\text { Total } \\
\text { Scope 2 }\end{array}$ & 126,398 \\
\hline
\end{tabular}

Source: Fast Retailing -- Sustainability Report 2017,

http://www.fastretailing.com/eng/sustainability/report/pdf/sustainability2017_en.pdf\#page=1\&pagemode $=$ thumbs \& $z$ oom $=80$

Fast Retailing plans to reduce carbon dioxide emissions in stores by $10 \%$ by 2020 (Fast Retailing - Sustainability Report 2017, http://www.fastretailing.com/eng/sustainability $/$ report/pdf/sustainability2017_en.pdf\#page=1\&pagemode=thumbs\&zoom $=80$.

For the purpose of more complex analyzes of greenhouse gas emissions by selected retailers, Table 16 shows the trend of greenhouse gas emissions for retailers in the United States and Great Britain. 
Table 16. Trend of greenhouse gases in US and UK

\begin{tabular}{|l|l|}
\hline Company & Annual Change in GHG Emissions (\%/year) \\
\hline UK Retailers & -3.67 (over 3 years) \\
\hline \hline Asda & -7.69 (4 years) \\
\hline Co-operative & -3.21 (4 years) \\
\hline Marks and Spencer & -2.22 (5 years) \\
\hline Morrisons & -0.88 (5 years) \\
\hline Sainsbury's & +5.28 (4 years) \\
\hline Tesco & 5.23 (over 3 years) \\
\hline US Retailers & 2.71 (5 years) \\
\hline Costco & -2.11 (4 years) \\
\hline Kroger & -6.05 (4 years) \\
\hline Lowe's & 0.98 (4 years) \\
\hline Sears & 2.19 (6 years) \\
\hline Target
\end{tabular}

Notes: a UK company based on Sullivan and Gouldson (2013). $b$ US company data based on company responses to the 2012 CDP survey Source: Sullivan, (2016)

In order to have more comprehensive understanding on differences Figure 12 presents comparative analysis of the greenhouse gas emission of US and UK retailers for the period 2006-2011.

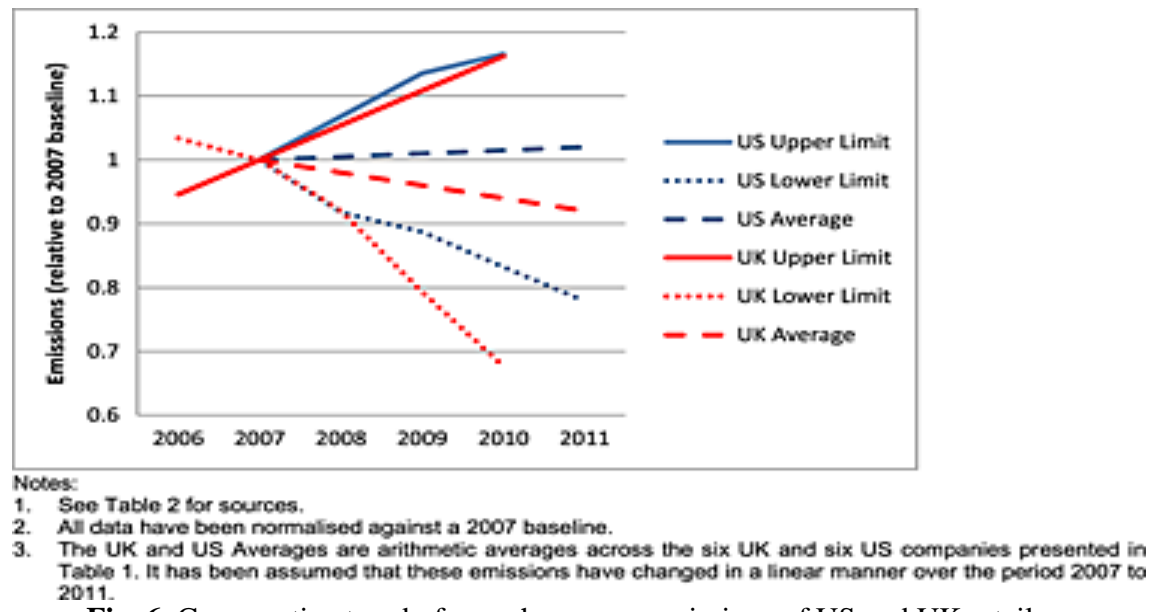

Fig. 6. Comparative trend of greenhouse gas emissions of US and UK retailers Source: Sullivan, (2016)

As well as in Fig. 6, the data in the given table show various annual changes in the greenhouse gas emissions between retailers UK and US. Thus, for example, in the UK, the highest annual positive percentage changes in greenhouse gas emissions are in Tesco $(+5.28)$, and in US in the retailer Costco (5.23). Concerning the negative annual changes in the greenhouse gas emissions, the largest are in the UK in Cooperative (-7.69) and in the US in Sears (-6.05). The conclusion is that there is, to some extent, higher reduction in greenhouse gas emissions from retailers in the UK than in the US. 


\section{Carbon dioxide emissions in retail companies of Serbia}

In Serbia there is a significantly smaller number of (domestic) retailers who disclose sustainable development reports compared to other countries, with the expectation that this number will increase significantly in the future. In this regard, the company of the Naftna Industija Srbije (NIS) is leading and for or a long period of time, it has regularly published a sustainable development reports, compiled in accordance with the G4 Global Reporting Initiative (GRI) Guidelines. Table 17 shows the amount of air pollutants emitted in the Naftna Industija Srbije for 2014, 2015 and 2016.

Table 17. Amount of emitted air pollutants in Naftna Industija Srbije

\begin{tabular}{||l|l|l|l|}
\hline & 2014 & 2015 & 2016 \\
\hline Emission $\mathrm{CO}_{2}(\mathrm{t})$ & 1457 & 3464 & 3649 \\
\hline Emission $\mathrm{NO}_{2}(\mathrm{t})$ & 601 & 1064 & 905 \\
\hline Emission of powdery materials (t) & 30 & 74 & 51 \\
\hline
\end{tabular}

Source: NIS Sustainable Development Report 2015 a 2016

In Naftna Industija Srbije, appropriate measures are continuously being undertaken in order to reduce the emissions of greenhouse gases in the future.

\section{Conclusion}

A growing number of retailers in the world are increasingly publishing reports on sustainable development. By their reputation, and because of its importance, other retailers will certainly tend to publish this report in the future. It provides the basis for a comparative analysis of environmental performance in retail from various aspects. In this report, special significance is given to trend of greenhouse gas emissions, in particular, carbon dioxide.

Carbon dioxide emissions in trade, in total and by sectors, vary by country. It is significantly higher in China than in Europe or the European Union. Likewise, carbon dioxide emissions are significantly higher in trade of France, Germany and Great Britain than in Greece, Croatia, Turkey and Serbia. Carbon dioxide emissions are higher in Croatia's trade than in Serbian.

These differences are due to the application of various ecological measures in business.

Carbon dioxide emissions differ in individual stages of the product life cycle, retail companies and product categories. Carbon dioxide emission generators in retail companies are: electricity, transport, ventilation, heating and cooking, refrigeration, and waste. The goal of all retailers is to take appropriate measures, primarily ecological in nature, to reach a planned reduction of carbon dioxide emissions in the future. Among other things, this is achieved with the increasing use of electricity from renewable sources (so-called "green energy"), by using modern ventilation, heating and cooking systems, refrigeration units, green logistics (ecological vehicles) and more efficient waste treatment. The effect of this is to improve the overall performance of retail companies, especially environmental.

\section{REFERENCES}

1. Ali Y et al. (2017). An analysis of CO2 emissions in Italy through the Macro Multiplier (MM) approach. Journal of Cleaner Production, 149, 238-250.

2. Bazan, E., Jaber, M. Y., \& Zanoni, S. (2017). Carbon emissions and energy effects on a twolevel manufacturer-retailer closed-loop supply chain model with remanufacturing subject to different coordination mechanisms. International Journal of Production Economics, 183, 394408.

3. Chatellier- Lorentzen, D. and Sheinbaum- Parado, C. (2017). Assessing the Impacts of Final Demand on CO2-eq Emissions in the Mexican Economy: An Input-Output Analysis. Energy and Power Engineering, 9, 40-54. 
4. Congcong, L. and Xiaojun, L. (2016). Simulation Research on Supply Chain Carbon Emission Model with SD. Management Science and Engineering, 10(4), 87-99.

5. Clune, C., Crossin, E. and Verghese, K. (2017). Systematic review of greenhouse gas emissions for different fresh food categories. Journal of Cleaner Production, 140 (2), 766-783.

6. Cucchiella, F., Gastaldi, M. and Miliacca, M. (2017). The management of greenhouse gas emissions and effects on firm performance. Journal of Cleaner production, xxx, 1-14, http://dx.doi.org/10.1016/j.jclepro.2017.02.170.

7. Eriksson, M. and Spångberg, J. (2017). Carbon footprint and energy use of food waste management options for fresh fruit and vegetables from supermarkets. Waste Management, 60, 786-799.

8. Igl, J. and Keller; F. (2017). Exploring greenhouse gas reduction opportunities for retailers in Fast Moving Consumer goods distribution networks. Transportation research Part D50, 55-69.

9. Ji, J., Zhang, Z. and Yang, L. (2017). Carbon emission reduction decisions in the retail - dual channel supply chain with consumers preference. Journal of Cleaner Production, 141, 852-867.

10. Jones, P., Comfort, D., Hiller, D. and Eastwood, I. (2005). Retailers and Sustainable development in the UK. International Journal of Retail \& Distribution Management, 33(3), 207 214.

11. Kahn, M.E. and Kok, N. (2014). Big-Box retailers and urban Carbon emissions: The case of Wal-Mart. Working Papers \# 5, 1-28.

12. Linda, K. and Donal, M-B. (2014). Reducing greenhouse gas emissions in the food sector: Effects of corporate responsibility. Kiel Working Paper, No. 1967, 1-39.

13. Li, F., Schwarz; L. and Haasis, H.D. (2016). A framework and risk analysis for supply chain emission trading. Journal Logistics. Research, 9 (1), 1-10.

14. Lukic, R. (2011). Evaluacija poslovnih performansi u maloprodaji. Beograd: Ekonomski fakultet.

15. Lukic, R. (2012). Sustainable Development of Retail in Serbia. Review of International Comparative Management, 13 (4). 574-586.

16. Lukic, R. (2013). Sustainable Cost Management in Retail. Review of International Comparative Management, 14(2), 268-280.

17. Lukic, R., Vojteski-Kljenak, D. and Jovancevic D. (2014). Food waste management. Management Research and Practice, 6(4), 23-39.

18. Lukic, R. (2016a). The impact of energy efficiency on performance in service sector. Economic and Environmental Studies, 16(2), 169-190.

19. Lukic, R. (2016b). Analysis of energy costs in retail trade. Management Research and Praktice, $8(4), 5-28$.

20. Lukic, R. and Lalic, S. (2016c). Energy Efficiency Food Retailers. In: $7^{\text {th }}$ International Agriculture Symposium "Agrosym 2016" Jahorina, 06-09 October 2016, Bosnia and Herzegovina, 2710-2717.

21. Lukic, R. (2017). Računovodstvo trgovinskih preduzeća. Beograd: Ekonomaki fakultet.

22. Makarov, I.A. and Sokolova, A.K. (2015). Carbon emissions embodied in Russia's trade. FIW Working Paper No 149, 1-33.

23. Martinuzzi, A. et al., (2011). "CSR Activities and Impacts of the Retail Sector", RIMAS Working Papers, No. 4, 1-31.

24. Patten, D. M., \& Zhao, N. (2014). Stand-alone reporting by U.S. retail companies. Accounting Forum, 38(2), 132-144.

25. Riboldazzi, S. (2016). Corporate Governance and Sustainability in Italian Large-Scale Retail Companies. European Scientific Journal, 12(16), 1-23.

26. Qin, J., Bai, X. and Xia, L. (2015). Sustainable Trade Credit and replenishment policies under the Cap-And-Trade and Carbon Tax Regulations. Sustainability, 7, 16340-16361.

27. Schönberger, H., Martos, J.L.G. and Styles, D (2013). Best Environmental Management Practice in the Retail Trade Sector. Join Research Centre, Report EUR 25998 EN, European Union.

28. Seebauer, S., Kulmer, V., Bruckner, M. and Winkler, E. (2016). Carbon emissions of retail channels: the limits of available policy instruments to achieve absolute reductions. Journal of Cleaner Production, 132, 192-203.

29. Solilová, V., Nerudová, D. (2015), Evaluation of Greenhouse Gas Emissions and Related Aspects: Case of the Czech Republic, Acta Universitatis Agriculturae et Silviculturae Mendelianae Brunensis, 63(1), 281-292. 
30. Sullian, R. and Gouldson, A. (2016). Comparing the Climate Change Actions, Targets and Performance of UK and US Retailers. Corporate Social Responsibility and Environmental Management, 23(3),129-136.

31. Wang, M., Gündüz, H.I., Herty, M. and Zhao, L. (2017). Quantity and location decision of fresh food distribution centres for a supermarket chain under carbon policies. In: Proceedings of the 50th Annual Hawaii International Conference on System Sciences, IEEE, Piscataway, 13611370.

32. Zhang, G., Liu, M. and Gao, X. (2014). Dynamic Characteristic Analysis of Indirect Carbon Emissions Caused by Chinese Urban and Rural Residential Consumption Based on Time Series Input-Output Tables from 2002 to 2011. Mathematical Problems in Engineering, 2014, Article Id 297637, 1-11.

33. Zheng, H. et al., (2017). China's Carbon Footprint Based on Input-Output Table Series: 19922010. Sustainability, 9, 307, 1-17.

34. https://cdn.corporate.walmart.com/9c/73/3f9abcef444397f2c771e081e095/2016-globalresponsibility-report.pdf\#page $=58 \& z 0 o m=$ auto, $-130,628$ (May 5, 2017)

35. http://sustainability.kroger.com/environment-energy-carbon.html (May 8, 2017).

36. https://corporate.bestbuy.com/wp-content/uploads/2016/06/fy16-full-report-final.pdf (May 8, 2017)

37. https://www.fmi.org/docs/sustainability/carbon-footprint-101-a-guide-for-foodretailers.pdf?sfvrsn=4\#page $=11 \&$ zoom $=$ auto, -121.85

38. https://www.tescoplc.com/media/392373/68336_tesco_ar_digital_interactive_250417.pdf

39. https://www.tescoplc.com/tesco-and-society/sourcing-great-products/reducing-our-impact-onthe-environment/our-carbon-footprint/

40. http://annualreport.marksandspencer.com/M\&S_PlanA_Report_2016.pdf

41. http://www.kingfisher.com/sustainability/files/reports/cr_report_2016/2016_Sustainability_Repo rt.pdf

42. https://www.tescoplc.com/tesco-and-society/sourcing-great-products/reducing-our-impact-onthe-environment/

43. http://www.ikea.com/ms/en_US/img/ad_content/IKEA_Group_Sustainability_Report_FY16.pf

44. http://sustainability.hm.com/content/dam/hm/about/documents/en/CSR/Report\%202016/HM_gr oup_SustainabilityReport_2016_FullReport_en.pdf

45. https://www.inditex.com/documents/10279/205236/Inditex+Annual+Report+2015+web.pdf/997 9097b-9e63-489a-ad16-a141b6b665b4

46. http://www.carrefour.com/sites/default/files/carrefour_2015_annual_activity_and_responsible_ commitment_report.pdf .

47. https://www.metrogroup.de/.../reports/metro-group-corporate-responsibility-report-2015

48. https://www.cr-aldinord.com/2015/wpcontent/uploads/sites/2/2016/04/ALDI_North_Group_NHB_Sustainability_Report_2015.pdf

49. https://www.cr-aldinord.com/2015/wpcontent/uploads/sites/2/2016/04/ALDI_North_Group_NHB_Sustainability_Report_2015.pdf.

50. https://www.aholddelhaize.com/media/1934/ahold-responsible-retailing-report-2015.pdf

51. https://www.aholddelhaize.com/media/3984/supplementary-report-on-sustainable-retailingperformance-2016.pdf

52. http://www.fastretailing.com/eng/sustainability/environment/co2_popup.html

53. http://www.fastretailing.com/eng/sustainability/report/pdf/sustainability2017_en.pdf\#page $=1 \&$ p agemode $=$ thumbs\&zoom $=80$

\section{Article history:}

- $\quad$ Received 1 October 2017

- $\quad$ Accepted 10 November 2017 